\title{
Philosophical roots of Quaternary Prevention
}

\author{
Raízes filosóficas da Prevenção Quaternária

\section{Raíces filosóficas de la Prevención Cuaternaria}

Daniel Widmer. MD, General Practitioner, Chargé de Cours. Institut Universitaire de Médecine de Famille (IUMF). Lausanne, Switzerland. drwidmer@belgo-suisse.com (Corresponding author)

\section{Abstract}

This article explores two philosophical dimensions of quaternary prevention since it represents the family doctors' response to overmedicalization. The first dimension refers to the theory of knowledge and the second to the theory of action. Despite their interconnectedness, they are addressed separately. Firstly, in the theories of knowledge (Epistemology) we argue that the positivism of Evidence-Based Medicine (EBM), so useful to select good practices, should be balanced against critical vision of the use of EBM coupled with a constructivist view through the narrative-based medicine. Secondly, in the theory of action (Ethics) we argue that the non-maleficence principle (primum non nocere) needs to be balanced by the beneficence principle. The latter is the primary medical obligation and doctors should cultivate this practical wisdom. Finally, some aspects of P4's future challenges are discussed such as health inequalities, interprofessional collaboration, responsibility, managerialism, and the integrative medicine, where a philosophical position should be considered.

\section{Resumo}

Este artigo explora duas dimensões filosóficas da prevenção quaternária, uma vez que esta representa a resposta dos médicos de família para a sobremedicalização. A primeira dimensão se refere à teoria do conhecimento e a segunda à teoria da ação. Apesar de suas interconexões, elas são abordadas separadamente. Em primeiro lugar, com relação à teoria do conhecimento (Epistemologia) argumenta-se que o positivismo da Medicina Baseada em Evidências (MBE), tão útil para selecionar boas práticas, deve ser equilibrado com uma visão crítica do uso da EBM, juntamente com uma visão construtivista através da medicina baseada em narrativas. Em segundo lugar, com relação à teoria da ação (Ética) argumenta-se que 0 princípio da não-maleficência (primum non nocere) precisa ser equilibrado pelo princípio da beneficência. Este último constitui-se obrigação médica primária e os médicos deveriam cultivar essa sabedoria prática. Finalmente, alguns aspectos dos futuros desafios da P4 são discutidos, tais como as desigualdades na saúde, a colaboração interprofissional, responsabilidade, gerencialismo, e a medicina integrativa, onde suas posições filosóficas deveriam ser consideradas

\section{Resumen}

Este artículo explora dos dimensiones filosóficas de la prevención cuaternaria, ya que esta representa la respuesta de los médicos de familia a la sobremedicalización. La primera dimensión se refiere a la teoría del conocimiento y la segunda a la teoría de la acción. A pesar de sus interconexiones, ellas serán discutidas en separado. En primer lugar, con respecto a las teorías del conocimiento (Epistemología) argumentase que el positivismo de la Medicina Basada en la Evidencia (MBE), tan útil para seleccionar las buenas prácticas, debería ser equilibrada con una visión crítica del uso de la $\mathrm{MBE}$, junto con una visión constructivista por medio de la medicina basada en la narrativa. En segundo lugar, con respecto a la teoría de la acción (Ética) argumentase que el principio de no maleficencia (primum non nocere) debe ser equilibrado por el principio de beneficencia. Este último es la obligación médica primaria y los médicos deberían cultivar esta sabiduría en la práctica. Finalmente, se discuten algunos aspectos de los retos futuros de la P4, como las desigualdades en salud, la colaboración interprofesional, la responsabilidad, el gerencialismo, y la medicina integral, donde sus posiciones filosóficas deberían ser consideradas.

\section{Keywords:}

Quaternary Prevention

Philosophy

Ethics

Evidence-Based Medicine

Epistemology

\section{Palavras-chave:}

Prevenção Quaternária Filosofia

Ética

Medicina Baseada em Evidências Epistemologia

\section{Palabras clave:}

Prevención Cuaternaria Filosofía

Ética

Medicina Basada en Evidencia Epistemología 


\section{Introduction}

Quaternary Prevention (P4), the family doctor's answer to overmedicalization, aims to protect the patient or population against the dangers of medicine. By asking the question: "Is acting always justified in medicine?", ${ }^{1}$ P4 opens our thinking to a philosophy of action, which belongs to the field of ethics. By questioning its justification, P4 seeks the best way to reduce uncertainty, which is rooted in a philosophy of knowledge, i.e. the field of Epistemology. Both philosophy of action and philosophy of knowledge are analysed in this article as two basic dimensions of P4. Although here they are addressed separately, knowledge and action are strongly intertwined: knowledge is a "regulative guidance", a prerequisite for planning, deciding, justifying or to understanding an action. As stated by John Dewey in his book "The Quest for Certainty":

Men will not easily surrender all regulative guidance in action. If they are forbidden to find standards in the course of experience they will seek them somewhere else, if not in revelation, then in the deliverance of a reason that is above experience. ${ }^{2}$ (p. 44)

The history of medicine has witnessed different paradigms of "regulative guidance", from magic-religious medicines (personalistic according Gartoulla), ${ }^{3}$ through naturalistic ${ }^{3}$ "rational" medicines which involved natural theories such as the Galenic humours theory, to practices based on cumulative observations and experiences (medical empiricism). Only recently the ascendancy of the randomized trial has given its importance to experimentation in medicine to base our decisions and actions on the best possible evidence. The ability to track down, critically appraise (for its validity and usefulness), and incorporate this rapidly growing body of evidence into one's clinical practice has been named by Sackett 'Evidence-Based-Medicine' (EBM). Sackett's ideal can be considered as a foundation of P4 as he states: "Might EBM help here by identifying which time - and resource-intensive manoeuvres should be dropped as we work to retain the effective ones and add new, more useful ones?" 4 (p. 16).

In EBM today there are decision helping tools whose usefulness is well established such as NNT (Number Needed to Treat). Despite these tools, professionals can take very different therapeutic options. ${ }^{5}$ Hence, it is an important question why and how professionals think in action? $?^{6}$ In other words, who necessitates further analysis and other epistemological models. Besides that, EBM can be used for purposes other than patient's interests, for example, to promote a new pharmaceutical product. Therefore, it is one of the roles of P4 to develop awareness about the misuses of science.

In order to expand on the subject this article describes the theories of knowledge upon which P4 can base its critical appraisal, followed by a discussion on the sceptical position in facing uncertainty. Then, it addresses the philosophy of action, trying to link the epistemological preconceptions to action as a consequence. Finally it discusses some P4's future challenges.

\section{Theories of knowledge}

As noted by Thomas, a number of theories of knowledge and theoretical models can be "weaved together to make sense of everyday experience"7 (p. 1) in family medicine, and all can be related to P4. For instance, Positivism is essential in seeking the best evidence for primary, secondary and tertiary prevention, as well as for treatment. However, in order to structure the search for the best evidence it deliberately simplifies the case, since the evidence comes from a population of individuals, each with its own singularities. When we group the data from these individuals, their singularities are lost and there is less certainty that the population results can be applied to individual patients. For example, is it possible to apply the evidence from men with atrial fibrillation who are otherwise healthy to a particular male patient who is a homeless and diabetic? In a complex scenario like this, The Systemic Model, ${ }^{8,9}$ which helps the practitioner to understand the patient's context and how it interacts with his condition, can be very useful in putting individual patients' conditions in a wider perspective.

Additionally, the Critical Theory ${ }^{10}$ takes into account the power relationship between peoples and tends to reduce disparities, constructing its knowledge from different perspectives (triangulation), primarily based on qualitative research. Quaternary Prevention uses such a model when it denounces the influence of pharmaceutical industry on medical knowledge (disease mongering, selling sickness), such as the publication bias favouring positive results or the attitude promoting check-ups in healthy people who do not need them (Table 1). 
Table 1. Critical model of power relationships.

\begin{tabular}{ll}
\hline \multicolumn{1}{c}{ Power } & \multicolumn{1}{c}{ Consequences } \\
\hline Pharma industry & Disease mongering \\
& Selling sickness \\
Academic competition & Publication bias \\
& Accent on quantitative over qualitative research \\
Insurances & Selection of good risk \\
Financial and social inequalities & Unnecessary check-ups in healthy high class people \\
\hline
\end{tabular}

Source: elaborated by the author.

Furthermore, there is often a lack of agreement between health professionals and patients, which means that "truth" is a co-constructed phenomenon. By recognising this disagreement, the Constructivist Model produces new outcomes from "the interaction between the inquirer and the inquired", ${ }^{7}$ which in medical practice could be portrayed by the physician-patient relationship. An example of the application of the constructivist model is the Narrative-Based Model ${ }^{11}$ adopted in primary care, which considers diagnosis and treatment as a co-construction process, where doctors help patients to develop a "better new story". In Balint's words, ${ }^{12}$ the doctor and the patient reach an "accepted compromise", avoiding the "confusion of tongues", when "each party is talking in a language not understood and apparently not understandable by the other". To avoid this confusion, they need to change "the level of diagnoses" from a diagnosis comprehending all physical signs and symptoms to a deeper level of diagnosis which implies an interpretation, more than an explanation. The area of philosophy that deals with interpretation as an iterative, empirically-based process, which takes into account the cultural and historical context leading to a better understanding is called Hermeneutics. ${ }^{10}$ These models are particularly important in quaternary prevention to avoid unnecessary tests and treatments that do not meet the patient's problems (Figure 1).

The question around P4 entails why, how and when to move "appropriately between these different theories". ${ }^{7}$ It is certainly possible to overmedicalise with EBM, as well as with hermeneutics. As an example, Michael Balint in his book "The doctor, his patient and the illness"12 described a case of a "too fast" psychological interpretation. The doctor that was

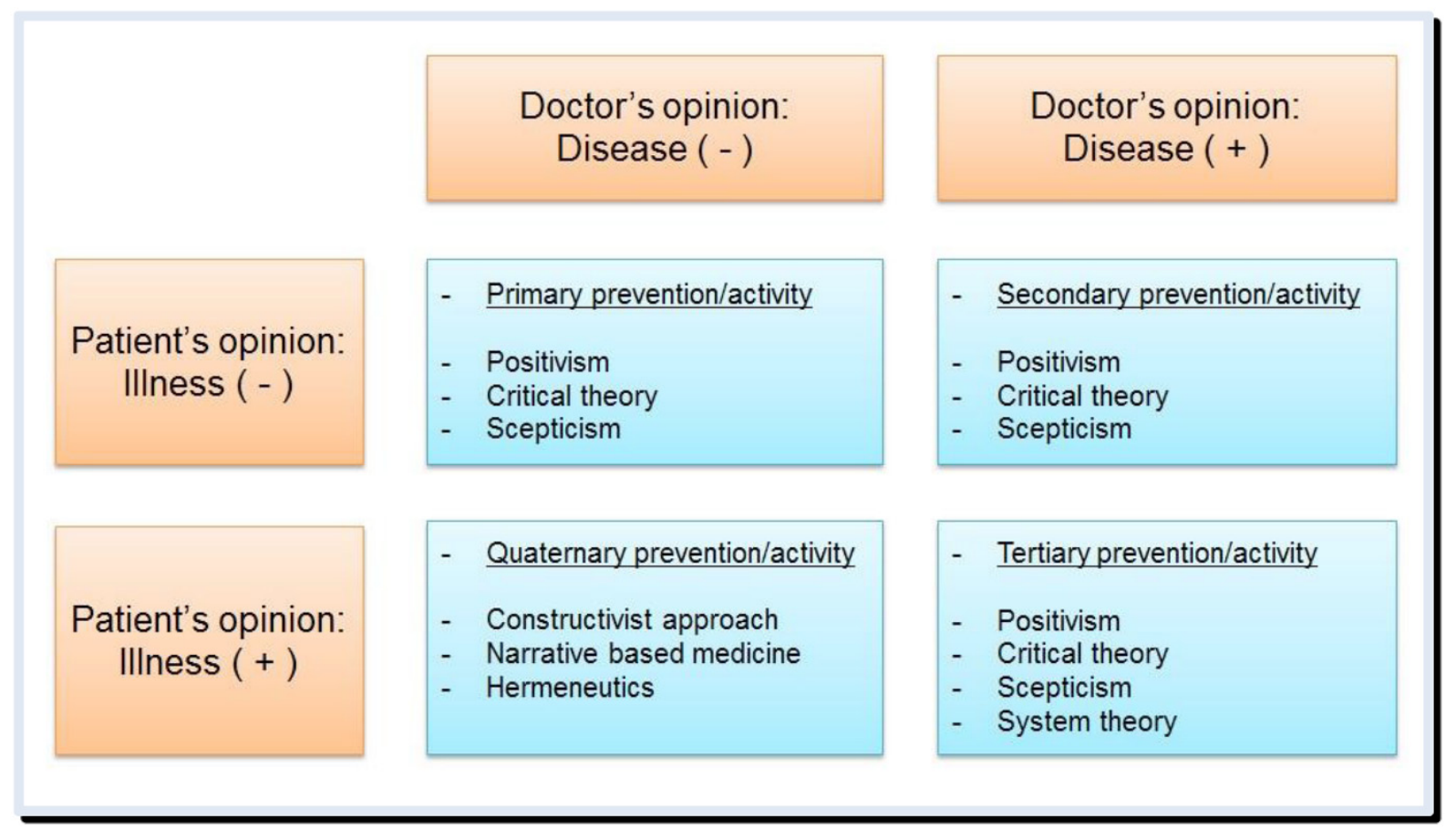

Figure 1. Epistemological models for Quaternary Prevention according to Jamoulle. ${ }^{13}$ 
reporting the case put emphasis on the psychological implications of the physical symptoms. However his colleagues felt that, although he was perhaps going in the right direction, "his speed was excessive for the patient". This illustrates the difference in pace between the physician and the patient which can be detrimental for therapeutic process. Similarly, an EBM practice based solely on guidelines might forget to create priorities together with the patient, leading to a deleterious practice. Especially in the case of patients with multimorbidity, it is essential to involve the patient in the decision-making process and to develop a patient-centred clinical method understanding the patient as a whole person. ${ }^{14}$

\section{Scepticism}

Medical scepticism is an old question (Table 2) which finds its source in the Hippocratic collection and is present until today when physicians profess disillusioned ideas, such as "evident today, wrong tomorrow", "maximal evidence, minimal compliance", or "evidence illuminates only where there is light". ${ }^{18}$ Scepticism can be the denial of the foundations of any certainty and can conduct to a widespread doubt, demotivation and professional burn-out. ${ }^{19}$ On the other hand, scepticism can manifest a critical spirit prone to examine and solve one's doubts. In this sense, scepticism is an ongoing research by bracketing prior knowledge and theories to concentrate on the lived experience of individuals. ${ }^{16}$ This bracketing is called "epochê" according to Sextus Empiricus, ${ }^{17}$ term also employed by Husserl's phenomenology. This creative kind of scepticism is also one the foundations of P4.

Table 2. Historical medical sceptics. ${ }^{15-17}$

Hippocrates (460-370 BC): 'The greater complexity (in Greek poikilotera) of these ills requires a more exact method of treatment. For it is necessary to aim at some measure. But no measure, neither number nor weight, by reference to which knowledge can be made exact, can be found except bodily feeling'. (Vol.1, p. 27) Sextus Empiricus (160-210 AD): 'Scepticism is an ability, or mental attitude, which opposes appearances to judgements... with the result that, owing to the equipollence of the objects and reasons thus opposed, we are brought firstly to a state of mental suspense...' (Epochê in Greek) (p. 7 )

Francisco Sanchez (1550-1623): 'Only individual objects exist: they are the only perceptions that are reached by the senses. From these perceptions alone must be a science... If you are in dispute, show me your famous universals in the nature'. (Original text in Latin, p. 33)

Source: elaborated by the author.

\section{More than EBM}

Summing up, EBM is a necessary but simplistic tool and it should be coupled to a critical vision that includes the humanities. The sceptical tradition reminds us that we work with individuals and encourages us to bracket our presuppositions and to centre ourselves on the lived experience. When it is not possible to experiment on so complex individual situations that we face, it is necessary to change the point of view. That can be summarised by the metaphor of Dewey on astronomy:

In astronomy we cannot introduce variation into remote heavenly bodies. But we can deliberately alter the conditions under which we observe them, which is the same thing in principle of logical procedure. By special instruments, the use of lens and prism, by telescopes, spectroscopes, interferometers, etc, we modify observed data. Observations are taken from widely different points in space and at successive times. By such means interconnected variations are observed. ${ }^{2}$ (p. 84).

\section{Theory of action}

If quaternary prevention promotes the abstinence of any action in presence of doubt (in dubio abstine), or in the absence of evidence, then there is the risk of therapeutic nihilism, ${ }^{20,21}$ of abandoning the patient without support. Inadequacy or insufficiency of care can be as dangerous as overmedicalization. A purely positivist model can lead physicians to forget the traditional rules of care. Hence, questioning the potential harms of therapeutic nihilism is also the role of P4 (Table 3). 
Table 3. Knowledge and action.

\begin{tabular}{ll}
\multicolumn{1}{c}{ Philosophy of knowledge } & \multicolumn{1}{c}{ Philosophy of action } \\
\hline Positivism (EBM) & In dubio abstine \\
Scepticism & Therapeutic nihilism \\
Critical theory & Non maleficence \\
Constructivism & Person centeredness \\
& Beneficence \\
& Virtues \\
Reflexivity / insight & Change of personality \\
\hline
\end{tabular}

Source: elaborated by the author.

The philosopher Gadamer ${ }^{22}$ wonders why we had to leave the pre-scientific stage of our experience of life that has long helped us to care and guide in sickness and facing death. Certainly P4 is interested in the hazards of medicine, but P4 should also question the tendency to prioritise the principle of non-maleficence (primum non nocere). As Pellegrino has stated "the primary obligation that unifies the theory of medical ethics is beneficence... The primary obligation is not non maleficence, which is a negative obligation required even by law". ${ }^{23}$ (p. 53)

In the original Hippocratic text, of Epidemics I, XI, $10-15,{ }^{15}$ there is no matter of priority for the non-maleficence principle: "make a habit of two things - to help, or at least to do no harm (p. 165)" ${ }^{15}$ Non-maleficence here is only an aspect of beneficience. ${ }^{21}$ Clinical decision making is not simply a statistical and probabilistic reasoning. ${ }^{23}$ Therefore, to prevent bad decisions, $\mathrm{P} 4$ should also promote the virtues of the physician and particularly "the virtue of prudence (phronesis) to which we turn to tell us how to resolve our understanding (p. 89)" 23 in situations of uncertainty and emergency. In this regard Benaroyo states:

Practical wisdom or prudence, inherited from Aristotle, embodies the ability of the caregiver to find the right standard in a unique situation ... This concept of prudence is forgotten under the influence of Kant's philosophy and development of modern scientific thought associated with it. ${ }^{24}$ (p. 85-86)

Prudence is a virtue and not a principle outside the human being. The recognition of virtue requires a personal reflexive insight and certainly, as Balint points out: "a limited, though considerable change in the doctor's personality". (p. 121) ${ }^{12}$ Prudence is an important condition of clinical expertise and there is a need for cultivating clinical expertise. As Sackett states "Good doctors use both individual clinical expertise and the best available external evidence and neither alone is enough" ${ }^{4}$ (p. 2) Thus, bearing in mind both epistemological and ethical position, doctors concerned by the risk of overmedicalization should take into account the general guidance summarised in Table 4.

Table 4. Some recommendations on epistemological and ethical position that doctors should take into account when addressing overmedicalization.

\begin{tabular}{|c|c|}
\hline Epistemological position & Ethical position \\
\hline Be aware of the epistemological models being used. & Be aware that care is the first evidence and that science comes after. \\
\hline Be aware of the consequences of choosing one epistemological model over others. & Try to link together the principles of beneficence and non-maleficence. \\
\hline Bracket any theory or model in order to focus on the patient's experience. & Cultivate practical wisdom, centred on the relation of doctor and patient. \\
\hline $\begin{array}{l}\text { Promote research across different areas (active scepticism): positive research, } \\
\text { critical, systemic, qualitative research, participatory action research, in order to get } \\
\text { different points of view. }\end{array}$ & Narrative based interest. \\
\hline
\end{tabular}

Source: elaborated by the author.

\section{Future challenges}

Given the future challenges of medicine, the "P4 doctor" will continue to worry about the excesses of medicine as well as about health inequalities. ${ }^{25,26}$ Physicians should cultivate ideas about philosophy of justice and be able to distinguish the two faces of justice: the necessary recognition of a patient's suffering and the right redistribution of care when resources are scarce. ${ }^{27}$ 
In promoting interprofessional collaboration to support multimorbid patients, ${ }^{28}$ "P 4 doctors" should be aware of the risk of over-organisation of care, that can culminate in a disruptive type of medicine. ${ }^{29}$ The existence of different professions, different conceptions, and different apostolic functions, ${ }^{12}$ increases the possibility of conflicts among these professionals. In this context, patient's agenda ${ }^{30}$ might be forgotten, leading to a situation of split therapeutic networks where the patient, according to his own agenda, divides the caregivers into good and bad ones, ${ }^{31}$ potentially generating more conflicts. Balint proposed the definition of the apostolic function:

It was almost as if every doctor had revealed knowledge of what was right and what was wrong for patients to expect and to endure, and further, as if he had a sacred duty to convert to his faith all the ignorant and unbelieving among his patient. ${ }^{12}$ (p. 216)

It is sometimes necessary to lower the threshold of caregiver's agenda and to choose the optimal minimum. ${ }^{32}$ In this regard a reflective self-awareness is required in order to promote a true $\mathrm{P} 4$ attitude.

Another change comprises the shared decision with other professionals or when the patient brings the question of responsibility in a context of uncertainty. ${ }^{33}$ The dilution of responsibility and the collusion of anonymity was described by Balint. ${ }^{12}$ For Arendt, ${ }^{34}$ (p. 28) the collective responsibility is impossible, since "there is no such thing as collective guilt or collective innocence; guilt and innocence make sense only if applied to individuals". Thus, physicians taking part in a network of carers, the coordination of care is unlikely to happen without the conviction and commitment of all the participants. According to Arendt, the question to $m y$ responsibility can be: why should I support the organisation and the care coordination? This implies the moral obligation to disobey, to "resist and to refuse to do anything that violates the promise to act in the patient's interests". ${ }^{23}$ (p. 39)

The New Public Management can also be a future concern for a P4 doctor. Managerialism, defined as the adoption and promotion "of private-sector or business practices as part of an attempt to refashion the welfare state (p. 230)", ${ }^{35}$ is a danger for the practice of medicine, as analysed by ethnographic studies ${ }^{35,36}$ more deeply than by quantitative (outcomes) studies, centred only on targets. ${ }^{37}$

A further challenge might be the social pressure for the introduction of Integrative Medicine. Rakel ${ }^{38}$ sees Complementary and Alternative Medicine (CAM) as a continuation of the Engel's biopsychosocial model in the hand of the primary care physician. As Rakel ${ }^{38}$ (p. 1108) states "the use of CAM without the direction and continuity of these clinicians will only fragment care further and increase costs". Thus, placing the whole field of medicine - including CAM - in the hands of the family doctor is questionable. This approach might risk transforming family doctor's activity into a Babel tower since some CAM refers to completely different medical models or philosophies such as Indian or Chinese medicine. It is also questionable to think that CAM will be the answer to the relational lack of scientific medicine.

The Balintian response for several of these questionings, as exemplified in various quotations, should certainly be remembered and revisited. In other words, quaternary prevention will have its place in an area that can also lead to overmedicalization. The help of qualitative research, particularly anthropology, should have important role in addressing these topics.

\section{Conclusion}

Quaternary prevention, by a critical view on medicine, should demonstrate a philosophical perspective on the profession both in the field of the theory of knowledge (Epistemology) and action (Ethics). Thus, P4 epitomises what Galen has pointed out that "the physician should also be a philosopher". ${ }^{39}$ (p.16)

\section{Acknowledgements}

The author would like to thank Dr. Michael Duncan and Dr. Armando Norman for their valuable contributions for the improvement of this article. 


\section{References}

1. Widmer D, Herzig L, Jamoulle M. Quaternary prevention: is acting always justified in family medicine?. Rev Med Suisse. 2014;10(430):1052-1056. PMid:24930150.

2. Dewey J. The quest for certainty. A study of the relation of knowledge and action. New York: Minton, Balch \& Co; 1929.

3. Gartoulla RP. Textbook of medical sociology and medical anthropology. Kathmandu: Research Centre fir Integrated Development; 2008.654 p.

4. Sackett DL, Richardson WS, Rosenberg W, Haynes RB. Evidence-based medicine. New York: Churchikk Livingstone; 1997.

5. Steel N. Thresholds for taking antihypertensive drugs in different professional and lay groups: questionnaire survey. BMJ. 2000;320(7247):14461447. http://dx.doi.org/10.1136/bmj.320.7247.1446. PMid:10827049.

6. Schön DA. The reflective practitioner: how professionals think in action. New York: Basic Books; 1983. 374 p.

7. Thomas P. General medical practitioners need to be aware of the theories on which our work depend. Ann Fam Med. 2006;4(5):450-454. http://dx.doi.org/10.1370/afm.581. PMid:17003147.

8. Sturmberg JP, Martin CM, editors. Handbook of systems and complexity in health [Internet]. New York: Springer New York; 2013 [cited 2014 Aug 23]. Available from: http://link.springer.com/10.1007/978-1-4614-4998-0

9. Sturmberg JP, Martin CM, Katerndahl DA. Systems and complexity thinking in the general practice literature: an integrative, historical narrative review. Ann Fam Med. 2014;12(1):66-74. http://dx. doi.org/10.1370/afm.1593. PMid:24445105.

10 Kuper A, Reeves S, Levinson W. An introduction to reading and appraising qualitative research. BMJ. 2008;337:a288.

11. Launer J. Narrative-based primary care: a practical guide. Abingdon: Radcliffe Medical Press; 2002.

12. Balint M. The doctor, his patient and the illness. Edinburgh: Churchill Livingstone; 2000.

13. Kuehlein T, Sghedoni D, Visentin G, Gervas J, Jamoulle M. Quaternary prevention: a task of the general practitioner [Internet]. PrimaryCare; 2010. [cited 2010 Nov 18]. Available from: http://www.primary-care.ch/docs/primarycare/archiv/de/2010/2010-18/2010-18-368_ELPS_engl.pdf.

14. Harris MF, Dennis S, Pillay M. Multimorbidity: negotiating priorities and making progress. Aust Fam Physician. 2013;42(12):850-854. PMid:24324984.

15. Hippocrates, Jones WHS, Withington ET. [Medical works]. Vol 1: Ancient medicine.Vol 4: Heracleitus on the Universe. Harvard University Press; 1923.

16. Sanchez F. II n'est science de rien. Paris: Klincksieck; 1984. 178 p. [cited 2015 Jun 18] Available from: http://gallica.bnf.fr/ark:/12148/bpt6k49823t.

17. Sextus Empiricus. Sextus empiricus: outlines of pyrrhonism. Cambridge: Harvard University Press; 1933.

18. Pilet F. Medicine based on proof (evidence based medicine)...or the Ouin-Ouin syndrome. Rev Med Suisse Romande. 2001;121(4):329-330. PMid:11400408.

19. Raynaud M. An Address on Scepticism in Medicine. BMJ. 1881;2(1076):268-273. http://dx.doi.org/10.1136/bmj.2.1076.268. PMid:20749969.

20. Johnston WM. Vienna, Vienna: the golden age, 1815-1914. New York: C.N. Potter; 1981. 332 p.

21. Gillon R. Philosophical medical ethics. Chichester: Wiley; 1986. 189 p.

22. Gadamer H-G. The enigma of health: the art of healing in a scientific age. Stanford: Stanford University Press; 1996.180 p.

23. Pellegrino ED. The virtues in medical practice. New York: Oxford University Press; 1993. 205 p.

24 Benaroyo L. Éthique et responsabilité en médecine. Genève: Éditions Médecine \& Hygiène; 2006. French ed.

25. Chatelard S, Vaucher P, Wolff H, Bischoff T, Herzig L, Panese F, et al. General practitioners facing social inequalities in health: which power to act? Rev Med Suisse. 2012;8(341):1061-1062, 1064-1066. PMid:22730642.

26. Chatelard S, Bodenmann P, Vaucher P, Herzig L, Bischoff T, Burnand B. General Practitioners Can Evaluate the Material, Social and Health Dimensions of Patient Social Status. PLoS ONE. 2014;9(1):e84828. http://dx.doi.org/10.1371/journal.pone.0084828.

27. Fraser N. Redistribution or recognition?: a political-philosophical exchange. London: Verso; 2003. 276 p.

28. Samuelson M, Herzig L, Widmer D. Future of interprofessional primary care in time of crisis. Rev Med Suisse. 2012;8(364):2254, 2256-2259. PMid:23240236.

29 May C, Montori VM, Mair FS. We need minimally disruptive medicine. BMJ. 2009;339:b2803.

30. Rodondi P-Y, Maillefer J, Suardi F, Rodondi N, Cornuz J, Vannotti M. Physician response to "by-the-way" syndrome in primary care. J Gen Intern Med. 2009;24(6):739-741. http://dx.doi.org/10.1007/s11606-009-0980-2. PMid:19390902.

31. Kernberg O. Borderline personality organization. J Am Psychoanal Assoc. 1967;15(3):641-685. http://dx.doi.org/10.1177/000306516701500309. PMid:4861171.

32. Stigler M, Quinche P, Bonsack C. Following "low threshold": the "optimal minimum" in the therapeutic approach to the difficult patient. Rev Med Suisse Romande. 1999;119(5):429-435. PMid:10384777.

33. Dowrick C, Frith L, editors. General practice and ethics: uncertainty and responsibility. London: Routledge; 1999.196 p. 
34. Arendt H, Kohn J. Responsibility and judgment [Electronic version]. New York: Schocken Books; 2003.

35. Grant S, Huby G, Watkins F, Checkland K, McDonald R, Davies H, et al. The impact of pay-for-performance on professional boundaries in UK general practice: an ethnographic study. Sociol Health IIIn. 2009;31(2):229-245. http://dx.doi.org/10.1111/j.1467-9566.2008.01129.x. PMid:18983422.

36. Checkland K, Harrison S, McDonald R, Grant S, Campbell S, Guthrie B. Biomedicine, holism and general medical practice: responses to the 2004 General Practitioner contract. Sociol Health IIIn. 2008;30(5):788-803. http://dx.doi.org/10.1111/j.1467-9566.2008.01081.x. PMid:18444956.

37 Harrison MJ, Dusheiko M, Sutton M, Gravelle H, Doran T, Roland M. Effect of a national primary care pay for performance scheme on emergency hospital admissions for ambulatory care sensitive conditions: controlled longitudinal study. BMJ. 2014;349:96423. http://dx.doi.org/10.1136/bmj.g6423.

38. Rakel D, editor. Integrative medicine. 3rd ed [Electronic version]. Philadelphia, PA: Elsevier Saunders; 2012. 1039 p.

39. Galenus DC. Traités philosophiques et logiques: des sectes pour les débutants, esquisse empirique, de l'expérience médicale, des sophismes verbaux, institution logique. Paris: Flammarion; 1998. 300 p. 